\title{
Pengaruh Penerapan IFRS, Jenis Industri dan Probabilitas Kebangkrutan terhadap Audit Delay (Pada Perusahaan LQ 45 yang Terdaftar di Bursa Efek Indonesia Periode 2013-2015)
}

\author{
Ina Amalia Nurahmayani. Pupung Purnamasari, Magnaz Lestira Oktaroza
}

STIE Sutaatmadja (STIESA) Subang

\begin{tabular}{|c|c|}
\hline INFO ARTIKEL & ABSTRAK/ABSTRACK \\
\hline $\begin{array}{l}\text { Histori Artikel : } \\
\text { Tgl Masuk : } 15 \text { Nov. } 2017 \\
\text { Tgl Diterima : } 21 \text { Feb. } 2018 \\
\text { Tersedia Online : } 5 \text { Mar. } 2018 \\
\text { Keywords: } \\
\text { FRS Application, Industrial } \\
\text { Type, Probability of Bankruptcy } \\
\text { and audit delay }\end{array}$ & $\begin{array}{l}\text { The delay audit is the period in completing the audit process } \\
\text { by an independent auditor from the closing date of the book } \\
\text { on } 31 \text { December until the date of signing of the independent } \\
\text { auditor's report. Audit delay can occur because of obstacles } \\
\text { in the implementation of the audit process. This study aims } \\
\text { to obtain empirical evidence on the effect of IFRS } \\
\text { implementation, industry type, and bankruptcy probability of } \\
\text { audit delay. The research method used in this research is } \\
\text { descriptive analysis method and quantitative method by } \\
\text { using multiple regression analysis. This research uses sample } \\
\text { data of LQ } 45 \text { index company that listed in Bursa Efek } \\
\text { Indonesia (BEI) during period 2013-2015. Sampling method } \\
\text { used is purposive sampling method. After selecting based on } \\
\text { purposive sampling method, there are } 14 \text { LQ } 45 \text { index } \\
\text { companies that meet the required sample criteria with } \\
\text { observation period for } 3 \text { years, so that } 42 \text { observations are } \\
\text { obtained. The results of this study indicate that the } \\
\text { implementation of IFRS effect on audit delay, Industrial Type } \\
\text { affect audit delay, Probability Bankruptcy does not affect } \\
\text { audit delay. The researcher recommends for further research } \\
\text { to use other sector companies for research, using a method } \\
\text { of determining samples other than purvosive sampling, } \\
\text { replacing other independent variables that may affect audit } \\
\text { delay. }\end{array}$ \\
\hline
\end{tabular}

\section{PENDAHULUAN}

Perkembangan dunia bisnis di Indonesia beberapa tahun terakhir ini sangat pesat. Hal ini ditandai dengan banyaknya perusahaan yang terdaftar di Bursa Efek Indonesia sebagai perusahaan go public. Setiap perusahaan yang telah terdaftar di BEl yang merupakan perusahaan go public wajib menerbitkan laporan keuangan pada setiap akhir periode yang disusun sesuai dengan standar akuntansi keuangan dan telah diaudit tepat waktu. Berkaitan dengan tuntutan akan kepatuhan terhadap ketepatan waktu dalam penyampaian laporan keuangan tersebut, Bursa Efek Indonesia (BEI) mewajibkan perusahaanperusahaan yang terdaftar untuk menyerahkan laporan keuangan tahunan yang telah diaudit oleh akuntan publik dalam waktu selambat-lambatnya pada akhir bulan ketiga (90 hari) setelah tanggal laporan keuangan tahunan. Hal 
tersebut berdasarkan Peraturan Bapepam Nomor X.K.2 , Lampiran Keputusan Ketua Bapepam dan LK Nomor KEP-346/BL/2011 tentang Kewajiban Penyampaian Laporan Keuangan Berkala Emiten dan Perusahaan Publik. Jika regulasi diatas dilanggar, maka akan dikenakan sanksi. Sanksi dapat berupa peringatan, sanksi administratif, dan sanksi denda.

Regulasi ini dimaksudkan agar perusahaan memberikan informasi yang lebih cepat dan akurat kepada investor mengenai kondisi perusahaan publik serta dalam rangka mengikuti perkembangan pasar modal global. Namun pada kenyataannya masih banyak perusahaan yang terlambat menerbitkan laporan keuangan.

Ketepatan waktu dalam pelaporan keuangan (timeliness of financial reporting) merupakan salah satu kriteria kualitas informasi akuntansi. Informasi dalam laporan keuangan agar dapat digunakan untuk membuat keputusan yang relevan maka laporan keuangan harus disajikan tepat waktu dan akurat. Nilai dari ketepatwaktuan pelaporan keuangan merupakan faktor penting bagi kemanfaatan informasi dalam laporan keuangan terkait dengan relevansi informasi. Hal ini karena semakin lama waktu laporan keuangan diterbitkan ke publik, tingkat akurasi dan relevansi informasi yang ada akan semakin menurun. Hal tersebut nantinya menyebabkan keputusan yang dihasilkan dari laporan tersebut menjadi kurang andal. Dalam rangka mencapai ketepatwaktuan dalam penyajian laporan keuangan auditor independen pada masa sekarang ini menghadapi beberapa masalah yang dapat menyebabkan lamanya proses penyelesaian audit (audit delay).

Salah satu faktor yang memiliki kaitan erat dengan audit delay adalah penerapan IFRS. Adanya pemberlakuan adopsi standar pencatatan dan pelaporan akuntansi yang berlaku internasional yaitu International Financial Reporting Standard (kemudian disebut IFRS). IFRS adalah standar yang dibuat secara internasional oleh International Accounting Standard Board (IASB) dengan tujuan memberi kumpulan standar penyusunan laporan keuangan perusahaan dunia. Dengan begitu adanya penerapan ke IFRS ini diduga dapat menjadi faktor yang mempengaruhi lamanya proses penyelesaian karena mengharuskan auditor untuk menyesuaikan atau beradaptasi dengan standar-standar yang telah berubah.

Faktor lain yang mempengaruhi audit delay adalah jenis industri. Pada umumnya jenis industri dibagi menjadi dua yaitu industri keuangan dan industri nonkeuangan. Perusahaan industri keuangan terdiri dari sektor bank, lembaga pembiayaan, perusahaan efek/sekuritas dan asuransi sedangkan perusahaan industri non-keuangan terdiri perusahaan manufaktur yaitu aneka industri, industri barang konsumsi, dan industri dasar dan kimia. Kaitannya dengan proses audit, menurut penelitian Iskandar dan Trisnawati (2010) menyatakan perusahaan sektor keuangan biasanya mengumumkan laporan keuangan yang lebih cepat karena hanya memiliki sedikit inventory, berbeda dengan perusahaan sektor non-keuangan seperti perusahaan manufaktur yang memiliki audit delay yang lebih lama karena memiliki inventory yang lebih kompleks sehingga auditor memerlukan waktu lebih lama untuk melakukan pekerjaan auditnya.

Faktor selanjutnya yang mempengaruhi audit delay adalah probabilitas kebangkrutan. Dalam dunia usaha, terjadinya kebangkrutan dalam 
suatu perusahaan juga dapat menjadi efek domino bagi berbagai pihak. Pihak-pihak internal perusahaan yang cenderung akan dirugikan dari adanya kebangrutan tersebut dapat dimulai dari karyawan pada perusahaan terkait dikarenakan terjadinya pemutusan kerja, kemudian para manajer atau pemimpin yang mengelola perusahaan, dan juga citra perusahaan yang hilang. Selain pihak internal, pihak eksternal juga akan terkena imbas dari tragedi kebangkrutan yang terjadi di suatu perusahaan, diantaranya adalah para investor dan kreditor, masyarakat disekitar, pemerintah, hingga dapat berakibat pada merosotnya kondisi perekonomian di negara yang berkaitan. Perusahaan yang cenderung mengalami kebangkrutan akan memiliki nilai $z$-score yang lebih rendah. Pendapat ini didasarkan pada penelitian yang telah dilakukan sebelumnya oleh Pesephony (2013:113) yang meneliti mengenai pengaruh probabilitas kebangkrutan terhadap waktu publikasi laporan keuangan. Persephony (2013:113) mengungkapkan bahwa probabilitas kebangkrutan memiliki pengaruh negatif yang signifikan terhadap publikasi laporan keuangan. Persephony menyimpulkan dengan model prediksi Altman $z$-score bahwa perusahaan yang memiliki probabilitas kebangkrutan yang tinggi dengan nilai $z$-score yang rendah cenderung akan mempublikasikan laporan keuangannya dengan tenggang waktu yang lebih panjang.

\section{TELAAH TEORI}

\section{Audit Delay}

Ketepatan waktu publikasi laporan keuangan sangat berpengaruh terhadap tingkat relevansi dan tingkat kepastian keputusan informasi, karena laporan keuangan auditan merupakan sumber informasi untuk pengambilan keputusan investasi. Lamanya auditor dalam mengerjakan auditnya (audit delay) dapat mempengaruhi ketepatan waktu publikasi laporan keuangan auditan.

Audit delay adalah jangka waktu dalam menyelesaikan proses audit oleh auditor independen dari tanggal tutup buku pada tanggal 31 Desember sampai dengan tanggal ditandatanganinya laporan auditor independen. Jadi, audit delay diukur secara kuantitatif dalam jumlah hari. Berdasarkan pemaparan diatas, Tambing Eko (2016) merumuskan audit delay sebagai berikut:

Audit Delay $=$ Tgl Lap. Audit - Tgl Lap.

Keuangan

Audit delay inilah yang dapat mempengaruhi ketepatan informasi yang dipublikasikan, sehingga akan berpengaruh terhadap tingkat ketidakpastian keputusan. Berdasarkan paparan di atas, salah satu pengguna informasi dalam laporan keuangan adalah investor, penanam modal atau investor yang membutuhkan informasi untuk membantu menentukan apakah harus membeli, menahan, atau menjual investasi dan mempertimbangkan kemampuan perusahaan dalam membayar dividen.

\section{Penerapan IFRS}

Penerapan IFRS, IFRS (Internasional Financial Reporting Standards) adalah suatu upaya untuk memperkuat arsitektur keungan global dan mencari solusi jangka panjang terhadap kurangnya transparansi informasi keuangan. Perusahaan di Indonesia yang menerapkan IFRS akan cenderung mengalami audit delay. Hal ini 
dikarenakan perusahaan yang telah menerapkan IFRS diwajibkan untuk melakukan pengungkapan yang luas, dengan begitu dibutuhkan upaya dan waktu yang lebih lama dalam melaksanakan audit (Hoodgendoorn, 2006). Selain itu Carlin et al. (2009) menyatakan bahwa kompleksitas IFRS tidak hanya pada perlakuan akuntansi, tetapi juga pada kesulitan untuk mematuhi pelaporan yang terinci.

Hasil penelitian yang dilakukan Margaretta dan Soepriyanto (2012), menyatakan bahwa penerapan IFRS tidak berpengaruh terhadap keterlambatan waktu penyapaian laporan keuangan dengan arah koefisien regresi positif. Arti dari penelitian ini yaitu penerapan IFRS mengakibatkan semakin tingginya tingkat keterlambatan penyampaian leporan keuangan.

Penelitian oleh Yacob dan Che Ahmad (2012) juga menguji tentang penerapan IFRS di Malaysia, dimana hasil penelitian tersebut menunjukkan bahwa penerapan IFRS di Malaysia memperpanjang masa audit delay yang dialami oleh perusahaan karena kompleksitas IFRS yang harus dipatuhi, sehingga menyebabkan auditor membutuhkan waktu yang lebih lama untuk mengaudit suatu laporan keuangan.

Berdasarkan penjelasan yang telah diuraikan, keterkaitan penerapan IFRS terhadap audit delay yaitu ketika suatu perusahaan menerapkan IFRS di dalam laporan keuangan nya akan menyebabkan auditor membutuhkan waktu yang lebih lama untuk mengaudit laporan keuangannya dikarenakan harus disesuaikan dengan standar yang baru yaitu yang berbasis IFRS, dibandingkan dengan perusahaan yang tidak menerapkan IFRS di dalam laporan keuangannya membuat auditor membutuhkan waktu yang jauh lebih singkat untuk mengaudit laporan keuangannya karena tidak terdapatnya standar baru yang berbasis IFRS.

H1 : Penerapan IFRS berpengaruh terhadap audit delay pada perusahaan indeks LQ 45 yang terdaftar di BEI periode 2013-2015.

\section{Jenis Industri}

Karakteristik industri yang berbedabeda dapat menyebabkan perbedaan rentang waktu dalam proses pelaksanaan audit maupun dalam publikasi pelaporan keuangan ke publik. Dalam penelitian ini, jenis industri dibagi menjadi dua kelompok yaitu industri nonfinancial dan industri financial. Industri non-financial cenderung mempunyai persediaan barang yang berbentuk fisik sedangkan industri financial cenderung mempunyai persediaan yang berbentuk moneter.

Menurut Ashnton et al (1987), perusahaan sektor financial mempunyai audit delay lebih pendek daripada perusahaan non financial. Hal ini disebabkan karena perusahaan financial tidak mempunyai saldo persediaan yang merupakan daerah paling sulit untuk diaudit, sehingga audit yang diperlukan tidak memerlukan waktu yang cukup lama. Hal ini sejalan dengan hasil penelitian Iskandar dan Trisnawati (2010), bahwa jenis industri berpengaruh negatif terhadap audit report lag.

Berdasarkan penjelasan yang telah diuraikan, keterkaitan jenis industri terhadap audit delay yaitu perusahaan non financial mempunyai audit delay yang lebih lama karena terdapat inventory atau persediaan yang lebih kompleks dimana sering terjadi salah saji yang material, karena itulah cakupan 
proses audit pada industri non financial lebih banyak dan lebih luas. Sedangkan, perusahaan financial mempunyai audit delay yang lebih pendek karena industri keuangan memilik persediaan atau inventory yang lebih sedikit atau mungkin tidak mempunyai sama sekali. Hal inilah yang membuat ruang lingkup proses audit pada perusahaan keuangan dapat dikurangi dan berdampak pada audit delay yang terjadi yaitu jauh lebih pendek dibanding perusahaan non financial.

H2 : Jenis Industri berpengaruh terhadap audit delay pada perusahaan indeks LQ 45 yang terdaftar di BEI periode 2013-2015.

\section{Probabilitas Kebangkrutan}

Kebangkrutan diartikan sebagai kegagalan perusahaan dalam menjalankan operasi untuk mencapai tujuannya. Kegagalan ekonomis berarti bahwa pendapatan perusahaan tidak mampu menutup biayanya sendiri. Kebangkrutan terjadi bila semua utang perusahaan melebihi nilai wajar aset totalnya. Dengan kata lain, perusahaan bernilai negatif atau berada dalam keadaan actual insolvency. Selain itu, dikenal juga istilah technical insolvency yaitu perusahaan dianggap gagal bila tidak dapat memenuhi kewajibannya pada saat jatuh tempo. Secara umum, penyebab kegagalan sebuah perusahaan adalah manajemen yang kurang kompeten. Tetapi penyebab umum kegagalan tersebut dipengaruhi oleh berbagai faktor lain yang saling terkait satu dengan lainnya.

Terdapat beberapa rumus yang dihasilkan dari berbagai penelitian untuk mendeteksi kebangkrutan, seperti Altman Z-Score, Springate Model, Zmijewski Model. Dalam penelitian ini penulis menggunakan rumus dari hasil penelitian Altman yang disebut sebagai $Z$ score. Rumus Z score yang digunakan dalam penelitian ini merupakan rumus terakhir yang dicetuskan oleh Altman setelah dua rumus sebelumnya. Rumus ini sangat fleksibel sehingga bisa digunakan untuk berbagai jenis bidang usaha perusahaan, baik yang go public maupun yang tidak, dan cocok digunakan di negara berkembang seperti Indonesia. Hasil penelitian rumus Z-Score ketiga untuk berbagai jenis perusahaan, sebagai berikut:

$\mathrm{Z}=6,56 \mathrm{X} 1+3,26 \mathrm{X} 2+6,72 \mathrm{X} 3+1,05 \mathrm{X} 4$

Sumber : Rudianto (2013:257)

Keterangan:

X1 = Modal Kerja/Total Aset

X2 = Laba ditahan/Total Aset

X3 $=$ EBIT/Total Aset

X4 = Nilai Buku Ekuitas/Nilai Buku Utang

\section{a. X1 (Modal Kerja/Total Aset)}

Modal kerja yang dimaksud dalam X1 yaitu selisih dari aset lancar dengan utang lancar, dan yang dimaksud dengan total aset yaitu total keseluruhan dari aset (aset lancar dan aset tetap).

Rasio ini digunakan untuk mengukur kemampuan perusahaan dalam memenuhi kewajiban jangka pendeknya dan untuk mengukur tingkat likuiditas aktiva perusahaan. Sebuah modal kerja yang bernilai positif menunjukkan kemampuan perusahaan untuk membayar tagihannya sedangkan apabila sebuah perusahaan memiliki modal yang bernilai negatif maka perusahaan tersebut akan mengalami kesulitan dalam memenuhi kewajibannya. 
b. X2 (Laba Ditahan/Total Aset)

Laba ditahan yang dimaksud dalam $\mathrm{X} 2$ yaitu total dari laba (retained earnings) yang telah ditentukan penggunaannya (appropriated) dengan laba (retained earnings) yang belum ditentukan penggunaannya (unappropriated).

Rasio ini merupakan pengukuran profitabilitas kumulatif atau laba ditahan perusahaan yang mencerminkan usia perusahaan serta kekuatan pendapatan perusahaan. Laba ditahan yang rendah mungkin menunjukkan tahun bisnis yang buruk atau pengurangan umur bagi perusahaan.

c. X3 (EBIT/Total Aset)

EBIT yang dimaksud dalam $\times 3$ yaitu laba sebelum bunga dan pajak yang merupakan jumlah dari laba usaha perusahaan.

Rasio yang termasuk dalam rasio profitabilitas ini memiliki fungsi untuk mengukur kemampuan perusahaan dalam menghasilkan laba aktiva yang digunakan atau dapat dikatakan sebagai ukuran produktivitas aset perusahaan.

d. X4 (Nilai Buku Ekuitas/Nilai Buku Utang)

Nilai buku ekuitas yang dimaksud dalam X4 yaitu jumlah saham yang beredar pada akhir tahun dikalikan dengan harga pasar per saham akhir tahun, dan nilai buku utang yang dimaksud adalah jumlah utang jangka pendek dan jangka panjang perusahaan.

Rasio ini digunakan untuk menggambarkan solvabilitas (leverage) yang berupa kemampuan finansial jangka panjang suatu perusahaan dan untuk mengetahui besarnya modal perusahaan yang digunakan untuk menanggung beban hutang.

Dari hasil analisa model Altman akan diperoleh nilai Z-Score yang dibagi dalam tiga tingkatan atau kategori, yaitu sebagai berikut:

Tabel 2.1

\section{Titik Cut-off Model Altman}

\begin{tabular}{|c|c|}
\hline Kategori & Standar Penilaian \\
\hline Zona Aman & $\mathrm{Z}>2,60$ \\
\hline Zona Abu-abu & $1,1<\mathrm{Z}<2,60$ \\
\hline Zona Berbahaya & $\mathrm{Z}<1,1$ \\
\hline
\end{tabular}

Sumber: Rudianto (2013:258)

Perusahaan yang cenderung mengalami kebangkrutan dengan analisis menggunakan model Altman zscore memiliki tingkat probabilitas kebangkrutan yang tinggi dengan nilai zscore yang cenderung kecil. Tingkat probabilitas kebangkrutan dengan nilai $z$ score yang kecil tersebut membuat perusahaan cenderung untuk menunda dalam penyampaian laporan keuangannya. Hal ini disebabkan ketika perusahaan mengalami kesulitan keuangan, cenderung akan terjadi audit delay, karena auditor memerlukan waktu yang lebih lama dalam proses audit dan juga auditor memerlukan data tambahan yang diperlukan untuk dapat menghasilkan opini yang sesuai dengan kondisi perusahaan tersebut.

Hasil yang berbeda ditunjukkan oleh perusahaan yang memiliki kondisi keuangan yang sehat dengan analisis menggunakan model Altman z-score memiliki tingkat probabilitas kebangkrutan yang rendah dengan nilai $z$-score yang cenderung besar. Tingkat probabilitas kebangkrutan dengan nilai $z-$ score yang besar tersebut membuat perusahaan cenderung untuk meningkatkan ketepatwaktuan dalam penyampaian laporan keuangan 
perusahaannya, sehingga audit delay yang terjadi menjadi lebih singkat bahkan mungkin tidak terjadi audit delay sama sekali.

Berdasarkan hasil penelitian Persephony (2013) mengenai pengaruh probabilitas kebangkrutan terhadap waktu publikasi laporan keuangan diperoleh tingkat signifikan sebesar 0,000, ini mencerminkan bahwa probabilitas kebangkrutan layak dipertimbangkan sebagai salah satu faktor yang dapat mempengaruhi audit delay sehingga dapat dipertimbangkan oleh auditor sebagai pertimbangan sebelum memberikan opini audit perusahaan. Perusahaan yang mengalami kesulitan keuangan akan mengalami audit delay yang lebih panjang jika dibandingkan dengan perusahaan yang tidak mengalami kesulitan keuangan. Hal ini sejalan dengan hasil penelitian Setyahadi (2012), bahwa probabilitas berpengaruh positif terhadap audit delay. Dapat disimpulkan bahwa, semakin kecil nilai Z-score akan mengakibatkan semakin besar probabilitas perusahaan mengalami audit delay yang lebih lama.

Berdasarkan penjelasan yang telah diuraikan, keterkaitan probabilitas kebangkrutan terhadap audit delay yaitu perusahaan yang memiliki tingkat probabilitas kebangkrutan yang tinggi dengan nilai $z$-score yang cenderung kecil akan mengakibatkan audit delay. Berbeda dengan perusahaan yang memiliki tingkat probabilitas kebangkrutan yang rendah dengan nilai $z$-score yang cenderung besar akan mengakibatkan audit delay menjadi lebih singkat bahkan mungkin tidak terjadi audit delay sama sekali.

H3 : Probabilitas Kebangkrutan berpengaruh terhadap audit delay pada perusahaan indeks LQ 45 yang terdaftar di BEI periode 2013-2015.

Berdasarkan penjelasan yang telah disampaikan di atas, hubungan antar variabel akan diperlihatkan dalam model penelitian berikut ini :

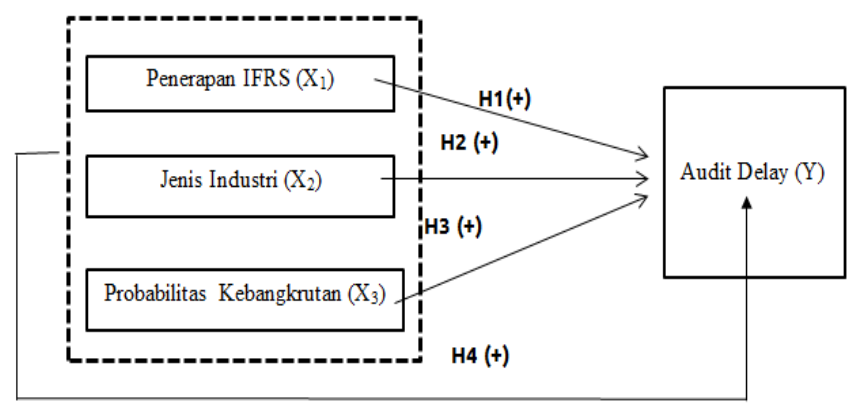

Gambar 2. 1 Model Penelitian

\section{METODE PENELITIAN}

\section{Sampel penelitian}

Seluruh perusahaan indeks LQ 45 yang terdaftar di PT Bursa Efek Indonesia periode 2013-2015 sebagai populasi dan sampel diperoleh dengan menetapkan kriteria tertentu (purposive sampling) sebagai berikut.

1. Perusahaan yang terdaftar di BEI dan konsisten masuk ke dalam kelompok perusahaan-perusahaan LQ 45 dari tahun 2013-2015.

2. Perusahaan yang memiliki data yang lengkap dan dapat digunakan sebagai sampel penelitian dari tahun 20132015.

3. Perusahaan yang menggunakan mata uang Rupiah dalam laporan keuangannya.

Penelitian menggunakan data sekunder, meliputi laporan keuangan tahunan, yang diperoleh dengan mengakses website www.idx.co.id. 


\section{Definisi Operasional dan Pengukuran Variabel}

Untuk memperjelas setiap variabel yang digunakan dalam penelitian ini, maka berikut diuraikan definisi operasional setiap variabel.

1. Audit delay adalah variabel dependen yang diukur secara kuantitatif dalam jumlah hari, yaitu jangka waktu dalam menyelesaikan proses audit oleh auditor independen dari tanggal tutup buku pada tanggal 31 Desember sampai dengan tanggal ditandatanganinya laporan auditor independen. Menurut (Tambing Eko, 2016) audit delay dapat dirumuskan sebagai berikut:

Audit Delay $=$ Tanggal Laporan Audit Tanggal Laporan Keuangan

2. Penerapan IFRS merupakan variabel independen yang bersifat dummy dengan ukuran kode 1 bagi perusahaan yang sudah menggunakan standar PSAK berbasis IFRS yang efektif 1 Januari 2015, sedangkan perusahaan yang belum menggunakan standar PSAK berbasis IFRS yang efektif 1 Januari 2015 diberi kode 0 .

3. Jenis Industri merupakan variabel independen yang bersifat dummy dengan ukuran kode 1 bagi perusahaan yang termasuk dalam jenis industri financial, sedangkan perusahaan yang tidak termasuk dalam jenis industri non financial diberi kode 0 .

Probabilitas Kebangkrutan merupakan variabel independen yang diukur dengan menggunakan rumus Altman $Z$-score jenis ketiga untuk berbagai jenis perusahaan (Rudianto,2013) yang diformulakan sebagai berikut:

$\mathrm{Z}=6,56 \mathrm{X} 1+3,26 \mathrm{X} 2+6,72 \mathrm{X} 3+1,05 \mathrm{X} 4$

Keterangan :

X1 = Modal Kerja/Total Aset

X2 = Laba ditahan/Total Aset

X3 = EBIT/Total Aset

X4= Nilai Buku Ekuitas/Nilai Buku Utang

\section{Model Analisis Empiris}

Model analisis dalam penelitian yang dilakukan adalah dengan teknik analisis regresi linear berganda. Persamaan regresi dalam penelitian sebagai berikut.

$$
Y=a+b 1 \times 1+b 2 \times 2+b 3 \times 3+e
$$

Keterangan:

$\mathrm{Y}=$ Audit Delay

$\mathrm{a}=$ Bilangan konstanta

$b=$ Koefisien regresi

$\mathrm{x} 1$ = Penerapan IFRS

$\mathrm{x} 2$ = Jenis Industri

x3 = Probabilitas Kebangkrutan

\section{HASIL PENELITIAN DAN PEMBAHASAN}

\section{Analisis Statistik Deskriptif}

Deskripsi statistik dari setiap variabel dapat dilihat pada Tabel 1 sampai dengan Tabel 4 (Terdapat pada lampiran). Berdasarkan hasil pengujian statistik deskriptif yang telah dilakukan dengan menggunakan SPSS Versi 16 nilai rata-rata (mean) variabel audit delay dari 14 sampel perusahaan indeks LQ 45 yang terdaftar di BEI pada tahun 2013-2015 dapat dijelaskan nilai minimum audit delay yang diperoleh adalah sebesar 28,00 yang terdapat pada PT Bank 
Mandiri (Persero) Tbk tahun 2015 sedangkan nilai maximum yang diperoleh adalah 89,00 yang terdapat pada PT Global Mediacom Tbk tahun 2015.

Rata-rata nilai audit delay adalah sebesar 64,5476, jumlah tersebut masih dibawah ketentuan Peraturan Bapepam Nomor X.K.2 yaitu 90 hari. Hal ini mencerminkan kepatuhan perusahaan yang terdaftar dalam indeks LQ 45 di BEI periode 2013-2015 dalam penyampaian laporan keuangannya.

Berdasarkan hasil pengujian statistik deskriptif yang telah dilakukan dengan menggunakan SPSS Versi 16 nilai ratarata (mean) penerapan IFRS dari 14 sampel perusahaan yang terdaftar dalam indeks LQ 45 di BEl pada tahun 20132015. Nilai minimum penerapan IFRS yang diperoleh adalah sebesar 0 sedangkan nilai maximum yang diperoleh adalah 1. Rata-rata nilai penerapan IFRS adalah sebesar 0,5238, hal ini menunjukkan bahwa sebagian besar perusahaan yang terdaftar dalam indeks LQ 45 di BEl periode 2013-2015 telah melakukan penerapan IFRS pada standar akuntansinya.

Perusahaan yang telah memiliki nilai 1 atau nilai maksimum pada statistik deskriptif di atas sejak tahun 2013 atau dengan kata lain telah menggunakan standar akuntansi berbasis IFRS yang efektif 1 Januari 2015 pada perusahaannya sejak tahun 2013 adalah pada PT AKR Corporindo Tbk, PT Global Mediacom Tbk, PT Lippo Karawaci Tbk, dan PT Tambang Batu Bara Bukit Asam (Persero) Tbk.

Berdasarkan hasil pengujian statistik deskriptif yang telah dilakukan dengan menggunakan SPSS Versi 16 nilai ratarata (mean) jenis industri dari 14 sampel perusahaan yang terdaftar dalam indeks LQ 45 di BEl pada tahun 2013-2015. Nilai minimum jenis industri yang diperoleh adalah sebesar 0 sedangkan nilai maximum yang diperoleh adalah 1 . Ratarata nilai jenis industri adalah sebesar 0,0714, hal ini menunjukkan bahwa sebagian besar perusahaan yang terdaftar dalam indeks LQ 45 di BEI periode 2013-2015 termasuk dalam sektor financial daripada sektor non financial.

Perusahaan yang telah memiliki nilai 1 atau nilai maksimum pada statistik deskriptif di atas sejak tahun 2013 atau dengan kata lain telah termasuk dalam sektor financial adalah Bank Mandiri (Persero) Tbk. Secara keseluruhan jenis industri perusahaan dalam indeks LQ 45 di BEl periode 2013-2015 yang dijadikan sampel lebih banyak termasuk dalam sektor non financial dibanding financial.

Berdasarkan hasil pengujian statistik deskriptif yang telah dilakukan dengan menggunakan SPSS Versi 16 nilai ratarata (mean) variabel probabilitas kebangkrutan dari 14 sampel perusahaan indeks LQ 45 yang terdaftar di BEI pada tahun 2013-2015 dapat dijelaskan nilai minimum probabilitas kebangkrutan yang diperoleh adalah sebesar $-414,18$ yang terdapat pada PT Alam Sutra Realty Tbk. tahun 2013 sedangkan nilai maximum yang diperoleh adalah 526,02 yang terdapat pada PP London Sumatera Indonesia Tbk. tahun 2015.

Rata-rata probabilitas kebangkrutan perusahaan yang terdaftar indeks LQ 45 di BEl periode 2013-2015 adalah sebesar 40,2418 yang lebih besar daripada tingkat batas atas tingkatan $z$-score sebesar 2,60. Ini berarti rata-rata perusahaan sampel tidak mengalami permasalahan keuangan yang dapat mengancam kelangsungan hidup usahanya. Secara keseluruhan probabilitas kebangkrutan perusahanperusahaan indeks LQ 45 yang dijadikan 
sampel dalam penelitian ini pada mayoritasnya adalah rendah atau dengan kata lain memiliki kondisi keuangan yang sehat.

\section{Uji Asumsi Klasik}

Uji normalitas menggunakan normal p-plots dalam program SPSS Versi 16. Berdasarkan Gambar 1 dapat dilihat bahwa data menyebar disekitar garis diagonal dan mengikuti arah garis diagonal atau grafik histogramnya menunjukkan pola distribusi normal, maka dapat disimpulkan bahwa data berdistribusi normal dan memenuhi syarat uji normalitas data. Uji multikolinearitas menghasilkan nilai tolerance dan variance inflation factor (VIF) yang mencerminkan tidak adanya multikolinearitas antarvariabel yang diujikan. Demikian pula hasil uji heteroskedastisitas (model glejser) dan uji autokorelasi (D-W) menunjukkan data terbebas dari heteroskedastisitas dan tidak mengandung autokorelasi sempurna (Ghozali, 2006: 104).

\section{Analisis Regresi Linear Berganda}

Pada penelitian ini, teknik analisis data yang digunakan untuk pengujian hipotesis adalah analisis regresi linear berganda. Berikut merupakan hasil penelitian mengenai pengaruh penerapan IFRS, jenis industri, dan probabilitas kebangkrutan terhadap audit delay yang akan dijelaskan pada tabel berikut
Tabel 5.

Hasil Analisis Regresi Berganda

\begin{tabular}{|c|c|c|c|c|c|}
\hline \multirow[b]{2}{*}{ Model } & \multicolumn{2}{|c|}{$\begin{array}{l}\text { Unstandardized } \\
\text { Coefficients }\end{array}$} & \multirow{2}{*}{\begin{tabular}{|c|}
$\begin{array}{c}\text { Stan- } \\
\text { dardized } \\
\text { Coeffi- } \\
\text { cients }\end{array}$ \\
Beta \\
\end{tabular}} & \multirow[b]{2}{*}{$\mathrm{T}$} & \multirow[b]{2}{*}{ Sig. } \\
\hline & B & Std. Error & & & \\
\hline 1 (Constant) & 65.756 & 3.394 & & 19.374 & .000 \\
\hline IFRS & 3.816 & 5.193 & .107 & .735 & .046 \\
\hline JNSI & -33.063 & 9.690 & -.483 & -3.412 & .002 \\
\hline PK & -.012 & .019 & -.092 & -.631 & .532 \\
\hline
\end{tabular}

a. Dependent Variable:AD

Sumber: Hasil Pengolahan Data SPSS

Versi 16, 2017

\section{Pengaruh Penerapan IFRS Terhadap Audit Delay}

Dari tabel di atas, dapat diketahui bahwa besarnya pengaruh antara penerapan IFRS adalah 3,816. Hasil pengujian hipotesis statistik dapat dilihat dari nilai signifikansi yang diperoleh, yaitu $0,046<0,05$. Hal tersebut mengindikasikan penerimaan hipotesis yang menunjukkan bahwa terdapat pengaruh penerapan IFRS terhadap audit delay.

Laporan keuangan yang telah menerapkan IFRS mewajibkan perusahaan untuk melakukan pengungkapan yang luas, dengan begitu dibutuhkan upaya dan waktu yang lebih lama dalam melaksanakan audit. Selain itu kompleksitas IFRS tidak hanya pada perlakuan akuntansi, tetapi juga pada kesulitan untuk mematuhi pelaporan yang terinci. Maka dari itu penerapan IFRS berpengaruh terhadap audit delay.

Hasil dari penelitian ini sejalan dengan penelitian yang dilakukan oleh Yacob dan Che Ahmad (2012) yang juga menguji tentang penerapan IFRS di Malaysia, dimana hasil penelitian tersebut menunjukkan bahwa penerapan IFRS di Malaysia memperpanjang masa audit delay yang dialami oleh perusahaan 
karena kompleksitas IFRS yang harus dipatuhi, sehingga menyebabkan auditor membutuhkan waktu yang lebih lama untuk mengaudit suatu laporan keuangan.

\section{Pengaruh Jenis Industri Terhadap Audit Delay}

Dari tabel di atas, dapat diketahui bahwa besarnya pengaruh antara jenis industri adalah $-33,063$. Hasil pengujian hipotesis statistik dapat dilihat dari nilai signifikansi yang diperoleh, yaitu 0,002 < 0,05 . Hal tersebut mengindikasikan penerimaan hipotesis yang menunjukkan bahwa terdapat pengaruh jenis industri terhadap audit delay.

Hal ini disebabkan perusahaan sektor financial biasanya mengumumkan laporan keuangan yang lebih cepat karena hanya memiliki sedikit inventory, berbeda dengan perusahaan sektor nonfinancial seperti perusahaan manufaktur yang memiliki audit delay yang lebih lama karena memiliki inventory yang lebih kompleks.

Proporsi inventory yang cenderung lebih rendah dibandingkan jenis asset lainnya menyebabkan audit delay pada perusahaan dalam industri financial lebih singkat. Hal ini karena auditor dapat mengabaikan atau menghabiskan sedikit waktu untuk melakukan audit terhadap inventory dimana material errors seringkali ditemukan. Selain itu, kebanyakan aset yang dimiliki oleh perusahaan financial adalah berbentuk aset moneter sehingga lebih mudah diukur bila dibandingkan dengan aset yang dimilki oleh perusahaan non financial yang kebanyakan berbentuk aset fisik. Pada umumnya industri non financial membutuhkan banyak aset berupa fisik seperti mesin dan peralatan untuk melangsungkan proses bisnisnya. Industri financial memiliki sistem informasi akuntansi yang lebih tersentralisasi dan terotomatisasi dibandingkan dengan industry non financial.

Hail dari penelitian ini sejalan dengan penelitian yang dilakukan oleh Ashnton et al (1987), yaitu perusahaan sektor financial mempunyai audit delay lebih pendek daripada perusahaan non financial. Hal ini disebabkan karena perusahaan financial tidak mempunyai saldo persediaan yang merupakan daerah paling sulit untuk diaudit, sehingga audit yang diperlukan tidak memerlukan waktu yang cukup lama.

\section{Pengaruh Probabilitas Kebangkrutan Terhadap Audit Delay}

Dari tabel di atas, dapat diketahui bahwa besarnya pengaruh antara probabilitas kebangkrutan adalah -0,012. Hasil pengujian hipotesis statistik dapat dilihat dari nilai signifikansi yang diperoleh, yaitu $0,532>0,05$. Hal tersebut mengindikasikan penolakan hipotesis yang menunjukkan bahwa tidak terdapat pengaruh probabilitas kebangkrutan terhadap audit delay.

Penolakan hipotesis di atas terjadi karena mayoritas perusahaan yang dijadikan sampel penelitian termasuk dalam zona aman. Artinya tidak terdapat probabilitas kebangkrutan. Jika dilihat dari data audit delay yang di alami oleh observan, rata-rata mendeketi nilai maksimum, namun masih di bawah batas pelaporan (90 hari setelah 31 Desember). Dengan demikian dapat disimpulkan tidak terjadinya probabilitas kebangkrutan pada sampel penelitian ini. Mayoritas pelaporan keuangan perusahaan mengalami audit delay namun masih di bawah batas pelaporan. 
Hasil penelitian ini sesuai dengan hasil penelitian sebelumnya oleh Widati dan Septy (2008) yang menyatakan bahwa tidak terdapat pengaruh yang signifikan dari salah satu rasio yang mencakup dalam pengukuran dengan model Altman z-score yang dapat memprediksi kebangkrutan yaitu rasio solvabilitas. Hasil penelitian tersebut bahwa tidak terdapat pengaruh yang signifikan dari rasio solvabilitas terhadap rentang waktu waktu penyelesaian audit laporan keuangan tahunan dan rentang waktu pengumuman laporan keuangan tahunan, yang artinya besar kecilnya utang terhadap total aktiva suatu perusahaan tidak menentukan cepat atau lambatnya penyelesaian audit dan pengumuman laporan keuangan tahunan ke publik. Hal ini disebabkan karena perusahaan tetap diharuskan melaporkan jumlah utang yang ada dalam perusahaan tersebut ke dalam laporan keuangannya agar laporan keuangan tersaji dengan relevan dan sesuai dengan fakta yang ada sehingga nama baik perusahaan tetap terjaga.

\section{Pengaruh Penerapan IFRS, Jenis Industri, dan Probabilitas Kebang- krutan Secara Bersama-sama Terhadap Audit Delay}

Penerapan IFRS, jenis industri, dan probabilitas kebangkrutan berpengaruh secara bersama-sama terhadap audit delay pada perusahaan indeks LQ 45 yang terdaftar di BEl pada tahun 20132015. Setelah dilakukan perhitungan dengan analisis regresi berganda dengan menggunakan program SPSS Versi 16 diperoleh nilai koefisien regresi Penerapan IFRS (IFRS) sebesar 3,816, nilai koefisien regresi Jenis Industri (JNSI) sebesar -33,063, nilai koefisien regresi Probabilitas Kebangkrutan (PK) sebesar 0,012, dan nilai konstanta sebesar 65,756 , persamaan garis regresi berganda sebagai berikut. $A D=66,756+$ 3,816 IFRS - 33,063 JNSI - 0,012 PK. Hasil Uji F pada tabel 6 menunjukkan bahwa $\rho$ value sebesar 0,013 yaitu lebih kecil dari nilai Alpha $(0,05)$ sehingga terjadi penolakan $\mathrm{H}_{0}$ yang berarti penerapan IFRS, jenis industri, dan probabilitas kebangkrutan memiliki pengaruh yang signifikan terhadap audit delay secara bersama-sama (simultan). Sehingga dapat disimpulkan bahwa penerapan IFRS, jenis industri, dan probabilitas kebangkrutan berpengaruh secara simultan terhadap audit delay pada perusahaan indeks LQ 45 yang terdaftar di BEI pada tahun 2013-2015.

Penerapan IFRS diharapkan dapat memudahkan bagi para pemangku kepentingan untuk membaca dan memahami laporan keuangan perusahaan terkait. Akan tetapi, kompleksitas IFRS menyebabkan auditor membutuhkan waktu yang lebih panjang dalam pengauditannya pada perusahaanperusahaan yang mengadopsi standar IFRS tersebut sehingga memperpanjang jangka waktu audit, yang berakibat pada keterlambatan penyampaian laporan keuangan auditan. Dengan demikian, adanya Penerapan IFRS belum mampu menentukan ketepatkwaktuan penyampaian suatu laporan keuangan yang diterbitkan perusahaan.

Jenis Industri merupakan pengaruh yang sangat signifikan dalam proses audit. Jenis perusahaan financial mengalami audit delay yang lebih pendek apabila dibandingkan dengan perusahaan jenis industri non financial.

Probabilitas Kebangkrutan juga
belum mampu menentukan tinggi
rendahnya kecenderungan suatu
perusahaan untuk menunda dalam
penyampaian laporan keuangannya
kepada publik. Hal ini disebabkan karena


ketapatwaktuan dalam penyampaian laporan keuangan telah diatur dengan jelas secara tertulis berdasarkan peraturan yang diterbitkan oleh BAPEPAM, sehingga perusahaaperusahaan yang telah listing dan go public akan memiliki kecenderungan menyampaikan laporan keuangannya secara tepat waktu untuk menghindari sanksi yang ditetapkan jika melanggar peraturan.

\section{KESIMPULAN DAN SARAN}

\section{Kesimpulan}

Penelitian ini meneliti tentang pengaruh penerapan IFRS, jenis industri, dan probabilitas kebangkrutan terhadap audit delay yang ditinjau dari jenis perusahaan indeks LQ 45 yang terdaftar di BEl selama periode 2013-2015, apakah perusahaan-perusahaan tersebut sudah menerapakan PSAK yang efektif 1 Januari 2015 di dalam laporan keuangan nya, dan apakah perusahaan-perusahaan tersebut mengalami probabilitas kebangkrutan yang dihitung dengan menggunakan rumus Altman Z-score ketiga untuk berbagai jenis perusahaan. Analisis yang dilakukan dengan menggunakan analisis data statistik deskriptif, statistik frekuensi, uji asumsi klasik yang terdiri dari empat bagian yaitu uji normalitas data, multikolinearitas, heterokedastisitas, dan yang terakhir autokorelasi. Analisis hipotesis dilakukan dengan analisis linear berganda yang terbentuk menjadi sebuah persamaan, analisis uji-t (parsial) dan analisis uji-F (simultan). Data sampel sebanyak 14 perusahaan indeks LQ 45 yang secara keseluruhan merupakan perusahaan yang terdaftar di BEl pada tahun 2013-2015.

\section{Saran}

Dari hasil pengujian penelitian ini, peneliti dapat memberikan saran sebagai berikut:

1. Bagi auditor disarankan untuk merencanakan pekerjaan lapangan dengan baik agar proses audit dapat dilakukan secara efektif dan efisien sehingga audit delay dapat ditekan seminimal mungkin dan laporan keuangan dapat dipublikasikan tepat waktu.

2. Bagi perusahaan sebaiknya terus bekerja secara profesional dan melakukan evaluasi berkala terhadap kinerja masing-masing agar dapat mengendalikan faktor-faktor yang dominan yang mempengaruhi lamanya audit delay.

3. Bagi peneliti selanjutnya disarankan untuk mengganti sub sektor lain. Selain itu peneliti yang akan datang disrankan untuk menggunakan metode penentuan sampel selain purvosive sampling seperti simple random sampling agar hasil penelitian berlaku umum.

\section{DAFTAR PUSTAKA}

Asthon, R.H., Willingham., Elliott. (1987). An Empirical Analysis of Audit Delay. Journal of Accounting Research. Volume 25/No.2/ 275-292.

Che-Ahmad, Ayoib. 2012. "Adoption of IFRS 138 and Audit delay in Malaysia". International Journal of Economics and Finance. Vol. 4, No. 1; January 2012. Malaysia.

Carlin, T. M., Finch C. dan Laili N. H. 2009. "Investigating Audit Quality among Big Four Malaysian Firms". Asian Review of Accounting. 17 (2). Pp 96114. 
Hoodgendom, M. 2006. "international Accounting Reguation and IFRS Inplementation in Europe and Betond-Experiences With First-Time Adoption in Europe". Accounting in Europe. Vol. 3, pp 23-26.

Iskandar, Meylisa Januar dan Trisnawati, Estralita. 2010. Faktor-Faktor yang Mempengaruhi Audit Report Lag Pada Perusahaan yang Terdaftar di Bursa Efek Indonesia. Jurnal Bisnis dan Akuntansi. 12 (3) Desember 2010, hal. 175-186.

Margaretta, Stephanny dan Gatot Soepriyanto. 2012. "Penerapan IFRS Dan Pengaruhnya Terhadap Keterlambatan Penyampaian Laporan Keuangan: Studi Empirias Perusahaan Manufaktur Di Bursa Efek Indonesia Periode Tahun 20082010.

Persephony Evita. 2013. Pengaruh Ukuran Perusahaan, Reputasi Kantor Akuntan Publik dan Probabilitas Kebangkrutan Tehadap Waktu Publikasi Laporan Keuangan dengan Audit Report Lag sebagai Variabel Intervening. Skripsi. Universitas Negeri Semarang, Semarang

Rudianto. 2013. Akuntansi Manajemen Informasi Untuk Pengambilan Keputusan Strategis. Jakarta: Erlangga.

Setyahadi, R. R. 2012. Pengaruh Probabilitas Kebangkrutan pada Audit Delay.
Doctoral dissertation, Tesis (dipublikasikan). Bali: Universitas Udayana.

Siti Aliyah Nur Kholishah. 2013. Pengaruh Penerapan IFRS, Ukuran Perusahaan, Profitabilitas, dan Komplesitas Terhadap Audit Delay (Studi Empiris Pada Perusahaan Manufaktur Yang Terdaftar di Bursa Efek Indonesia Pada Tahun 2008-2011). Skripsi. UIN Syarif Hidayatullah,Jakarta.

Tambing Eko. 2016. Analisis Determinan Audit Delay pada Perusahaan LQ 45 yang Terdaftar pada BEI Tahun 20112015. Skripsi. Universitas Hasanuddin Makassar, Makassar.

Tri Diana Wahyu Indriani. 2014. Pengaruh Ukuran Perusahaan, Profitabilitas, Solvabilitas, Jenis Industri dan Ukuran Kantor Akuntan Publik Terhadap Audit Delay (Studi Kasus Pada Perusahaan Indeks LQ 45 Yang Terdaftar Di Bursa Efek Indonesia Tahun 2010-2013). Skripsi. UNY, Yogyakarta.

Widati, Listyorini Wahyu dan Fina Septy. 2008. Faktor-faktor yang Mempengaruhi Rentang Waktu Penyajian Laporan Keuangan Ke Publik. Jurnal Penelitian Fokus Ekonomi Volume 7 Nomor 3. Semarang: Unisbank.

http ://w.w.w.idx.co.id 